\title{
Scots pine (Pinus sylvestris L.) ecosystem macronutrients budget on reclaimed mine sites-stand trees supply and stability*
}

\author{
Marcin Pietrzykowski
}

Department of Forest Ecology, Agricultural University of Kracow, Krakow, Poland; rlpietrz@cyf-kr.edu.pl

Received 12 February 2010; revised 24 March 2010; accepted 7 April 2010.

\section{ABSTRACT}

The aim of this study was to determine the sources, accumulation rate and relationships between macronutrients in reclaimed mine soils (RMS) and aboveground plant biomass on external slopes of lignite mines in central Poland. The study was conducted on two different types of sites with 10-year-old Scots (Pinus sylvestris L.) pine stands located on Quaternary loamy sands (QLS) and on Tertiary acidic carboniferous sands following neutralisation (TCS). The control plot was located in the same vicinity on an external slope in a natural pine ecosystem on a Haplic Podzol in a young mixed coniferous forest habitat (NPE). The nutrient resources, apart from N, were higher in RMS than in comparable Haplic Podzols, however, $\mathbf{N}$ primarily accumulated in the mineral horizons. In forest soils, the main macronutrient resources were accumulated in organic horizons, which in natural soils of coniferous forest habitats constitute the main source of nutrients. The proportion of individual macronutrients accumulated in the biomass vs. pools in soil was much lower on the external slope RMS than in the natural site, which in view of the potential richness of RMS, indicated poorer sorption and utilization of macronutrients in aboveground plant biomass than in natural habitats. Other important linear correlations ( $p$ $=.05$ ) were found between the sources of nutrients in RMS and elements accumulated in biomass (most clearly in case of $\mathrm{K}, \mathrm{Ca}$ and $\mathrm{Mg}$ ), which indicates important relationships between soil and vegetation in the first stages of ecosystem development as stimulated by reclamation.

\footnotetext{
${ }^{*}$ This work was sponsored by the grant from Norway through the Norwegian Financial Mechanism
}

Keywords: Reclamation; Scots Pine; Ecosystem; Macronutrients

\section{INTRODUCTION}

As is true in many contemporary environmental problems, the rehabilitation of a drastically disturbed terrestrial system, such as lands mined for coal and minerals, requires site-specific knowledge to ensure the reclamation strategies chosen will be sustainable [1-16]. In central Europe, a large proportion of post-mining landscapes are reclaimed to forest.

From an ecological point of view, reclamation is a process of restoring the whole ecosystem [2]. The ecosystem, according to the traditional definition by Tensley, A.G. [17], should consist of an integrated system of biotic and abiotic elements where all the trophy layers contain a complete set of species ensuring the circulation of matter and energy flow. A complete assessment of the reclamation processes should take into consideration many ecological factors [18]. It is therefore important to determine the soil development rate including the depth of organic horizons, nutrient accumulation rates, balance of elements [3,19-22] and plant community devel- opment. Plant community parameters should include the number of species, biodiversity of communities, and the proportion of species characteristic of forest and nonforest communities [23-25].

Chemical compound pools (mineral and organic substrates) are the inanimate elements of the ecosystem (the biotope), whereas plant and animal communities are considered the animate elements of the ecosystem (biocenosis) [26]. In the course of reclamation treatment, all the factors which affect the functionality of the ecosystem are developed from essentially zero such as in primary succession $[14,15]$. Creation of conditions for efficient circulation of matter and energy flow between the biotope and the biocenosis determines the success of the 
reclamation treatment which stimulates the process of ecosystem restoration [2]. However, the key question is when the restored biological systems cycle nutrients at rates that meet their demand without compromiseing their productivity $[2,11,19,27,28]$.

The stand of trees is an element within animate forest ecosystems which most distinctly modifies their microclimate, light and biochemical conditions for other organisms undergoing succession. The condition and growth of stands of trees introduced to reclaimed areas directly depend on the capacity of substrates (parent rock) and the developing soil to meet the nutrient requirements which gradually increase along with the growth of biomass. There are differences between ecosystems restored on post-mining sites and natural forest ecosystems [22, 27] and they include a disturbed element circulation cycle, and low percentage of organic matter developed in situ. These conditions can significantly limit the pool of available elements for nutrient cycling in tree stands [29], and these cycles are also occasionally limited by direct acid-metal phytotoxicity in reclaimed mine soils (RMS).

The aim of this work was to 1) determine the sources of soil macronutrient elements: $\mathrm{C} ; \mathrm{N} ; \mathrm{S} ; \mathrm{P} ; \mathrm{K} ; \mathrm{Ca} ; \mathrm{Mg}$; $\mathrm{Na}$, and 2) to determine relationships between total and available forms in RMS and 3) their accumulation in the biomass of pine stands growing in the KWB 'Bełchatów' (in central Poland) reclaimed opencast lignite mine spoil heap. The study was conducted on stands of pine trees since the Scots pine (Pinus sylvestris L.) is one of the main species introduced when reforesting post-mining sites in central Europe [30] due to its low habitat requirements and pioneering character [31].

\section{MATERIALS AND METHODS}

\subsection{Study Site}

The study was conducted in the top portion of an opencast lignite mine spoil heap, 'Bełchatów', in central Poland (N 51 13.196; E 19 25.569). The spoil heap ranged in height from 120 to $180 \mathrm{~m}$ and covers an area of 1480 ha; including slopes (embankments and shelves) of 1165 ha, and a summit portion of 318 ha. Climate in the area is transitional and changeable due to clashes between polar maritime air masses and polar continental air masses. The average annual temperature is $7.6^{\circ} \mathrm{C}$; the annual amplitude is $21^{\circ} \mathrm{C}$; the growing period lasts $200-210$ days, and total precipitation is $580-600 \mathrm{~mm}$ [32]. The site is located mostly on a mixture of Quaternary loamy sands, and sand with gravel, which occasionally consists of loam, bouldery clay and clay. There are also areas of Tertiary sandy strata with loam and clay, frequently carbonated and sulphurised, which are very acidic, display- ing phytotoxic properties $[33,34]$. The reclamation treatment on the top portion of the spoil heap consisted of NPK mineral fertilisation $(\mathrm{N}-60, \mathrm{P}-70$ and $\mathrm{K}-60$ $\left.\mathrm{kg} \cdot \mathrm{ha}^{-1}\right)$, and sowing a mixture of grass and leguminous plants $\left(60 \mathrm{~kg} \cdot \mathrm{ha}^{-1}\right)$. The tertiary pyritic strata was earlier neutralised with bog lime incorporated into the surface horizon to a depth of $40 \mathrm{~cm} \mathrm{[34].} \mathrm{The} \mathrm{area} \mathrm{was} \mathrm{later}$ ref- orested mainly with $50 \%$ Scots pine (Pinus sylvestris L.) and 30\% common birch (Betula verrucosa Ehrh.). The predominantly 1 -year-old seedlings were planted on a $0.7 \mathrm{~m}$ length $\times 1.5 \mathrm{~m}$ width spacing [34].

\subsection{Field Studies and Laboratory Analyses}

The study plots $(10 \times 10 \mathrm{~m})$ were located in approximately 12 to 17 -year-old stands of pines on the top portion of the spoil heap (4 replications for each variant): one on the potentially fertile Quaternary loamy sand (QLS) and two on Tertiary carboniferous and pyritic sand following neutralisation (TCS). The control plot (NPE) was located in a forest in the vicinity of the spoil heap in a 17-yearold stand of pine trees, in a mixed coniferous forest habitat, ideal for this species.

Dendrometric measurements of the tree stands were made including diameter of trees at the root collar, diameter at a height of $1.3 \mathrm{~m}$ (i.e., $\mathrm{DBH}$ ) and their overall height (h0). Later, 35 study trees were selected proportionally to their diameter, and were cut down and weighed (the branches were weighed separately) and their foliage was tested. Foliage samples were taken to determine water content and elemental composition in the laboratory. Next, 22 tree root systems were excavated; the diameter at the root collar was measured, as were the maximum horizontal and vertical range of the roots. Roots were weighed later. Woody tissue was sampled to determine water content and elemental composition. The measurements and the obtained data were used to develop empirical equations to determine the aboveground tree biomass and root systems on the spoil heap $\left(\mathrm{Mg} \cdot \mathrm{ha}^{-1}\right)$ [empirical equations by Socha, 2006; unpublished data]. Fine roots less than $2 \mathrm{~mm}$ in diameter were assessed using cylinders $\left(250 \mathrm{~cm}^{3}\right)$ for sampling in 3 replications at three depths $(0-8 \mathrm{~cm}, 8-50 \mathrm{~cm}$ and $50-110 \mathrm{~cm}$ ) from one plot per each variant on the spoil heap. In the lab, the samples were rinsed, dried and the roots were weighed. The aboveground biomass of the herbaceous vegetation was determined using the harvest method at the peak of the vegetation period, from $1 \times 1 \mathrm{~m}$ squares in 3 replications located diagonally on each study plot. Next, herbaceous vegetation was sampled to determine water content and elemental composition in the lab.

In the course of the soil study, a $110-\mathrm{cm}$ soil pit was 
dug in the spoil heap and another $150 \mathrm{~cm}$ pit in the control plot was dug, and soil morphology was described. To determine volumetric density, samples of intact structure were collected into $250 \mathrm{~cm}^{3}$ cylinders in 3 replications for each horizon. Apart from soil pits, 3 bore holes were made in each plot with soil drills [from Eijkelkamp] and mixed samples were collected to determine the content of elements and other physical and chemical soil properties from depths of: 0-8 cm (organic mineral horizons displaying some features of parent rock $\mathrm{AiC}$ ); from $8-50 \mathrm{~cm}$, and from $50-110 \mathrm{~cm}$ (parent rock horizons C). Samples of the organic horizon (raw humus - OL/f) were collected in autumn after the vegetation period from $1 \times 1 \mathrm{~m}$ plots in 3 replications from each plot; the mass was assayed on the spot and mixed samples were collected for lab tests.

In the laboratory, soil samples were dried and screened with a $2 \mathrm{~mm}$ screen, and samples from the OL/f horizon grounded after drying. The following factors were determined in the soil samples: particle size distribution using areometrical method, $\mathrm{pH}$ potentiometrically in $\mathrm{H}_{2} \mathrm{O}$ and in $1 \mathrm{M} \mathrm{KCl}\left(1: 2.5\right.$ ratio); organic carbon $\left(\mathrm{C}_{\mathrm{org}}\right)$ and total sulphur $\left(\mathrm{S}_{\mathrm{t}}\right)$ content using the infra-red absorption method, and total nitrogen $\left(\mathrm{N}_{\mathrm{t}}\right)$ using the thermal conductivity method with the "Leco CNS 2000" analyser; basic exchangeable cations $\mathrm{Na}^{+}, \mathrm{K}^{+}, \mathrm{Ca}^{2+}, \mathrm{Mg}^{2+}$ in $1 \mathrm{M}$ $\mathrm{NH}_{4} \mathrm{Ac}$ by AAS detection; the content of total elements: $\mathrm{Na}, \mathrm{Mg}, \mathrm{Ca}, \mathrm{K}$ after digestion in the mixture of $\mathrm{HNO}_{3}$, $(\mathrm{d}=1.40)$ and $60 \% \mathrm{HClO}_{4}$ acid in $4: 1$ ratio using the AAS method. Phosphorus (P) in a form assimilated by plants was assayed using the Egner-Riehm method in calcium lactate extract $\left(\left(\mathrm{CH}_{3} \mathrm{CHOHCOO}\right)_{2} \mathrm{Ca}\right)$ acidified with hydrochloric acid to $\mathrm{pH} 3.6$ and in total form using the molybdate blue colorimetry method from extracts in $\mathrm{HClO}_{4}[35,36]$. Soil subtypes were defined according to FAO taxonomy [37].

In mixed samples of Scots pine needles and herbaceous vegetation from the undergrowth (one sample for each study plot) the C, N, S content was assayed on the 'Leco CNS 2000' analyser; $\mathrm{Na}, \mathrm{K}, \mathrm{Ca}, \mathrm{Mg}$ after digestion in the mixture of $\mathrm{HNO}_{3}(\mathrm{~d}=1.40)$ and $60 \% \mathrm{HClO}_{4}$ acid in a ratio of $4: 1$ using the AAS method and $\mathrm{P}$ using molybdate blue colorimetry from an extract in $60 \%$ $\mathrm{HClO}_{4}[35]$.

The results, i.e., the total pools of elements in soil, were statistically analyzed using the Statistica 6.1 programme. Differences between mean values of features from two independent groups (QLS and TCS) were tested. Distributions were compared to normality using the Shapiro-Wilks test. Next, to compare mean values of features in two variants, a t-student test was applied for independent variables $(p=0.05)$. Correlations between sources of elements in available and exchangeable forms in soil versus accumulation in aboveground community biomass $(p=0.05)$ were also tested.

\section{RESULTS AND DISCUSSION}

\subsection{Soil Characteristic on the Spoil Heap}

In the top portion of the spoil heap the soils were classified as Urbic Anthrosols with initial development of organic OL/f horizons which produced semi-mor-type humus at the development stage with raw humus and a thin layer of initial transitional organic-mineral horizons reflecting the features of the parent rock (AiC). In both soil types (QLS and TCS), rock type was mixed due to nonselective dumping of the rock cap. In QLS, soils developing from these strata exhibited predominantly sandy clay textures with an average of $28 \%$ silt and $4 \%$ clay. They were also sometimes interbedded with clay $(43 \%$ silt fraction and $9 \%$ clay fraction) or sand. The soil bulk density averaged $1.67 \mathrm{~g} \cdot \mathrm{cm}^{-3}$. In the TCS soil profile, there were remains of bog lime which had been used as a neutraliser. Soils developing on these strata exhibited lighter and more varied sandy textures, sometimes grading to loamy sand. The bulk density of the strata averaged $1.68 \mathrm{~g} \cdot \mathrm{cm}^{-3}$. In the control plot in the neighboring forest ecosystem, the soil was a Haplic Podzol formed on fluvioglacial sandy strata with only up to $1 \%$ silt and up to $5 \%$ clay.

In the reclaimed areas features such as texture, soil cohesion and the neutralisation depth of toxically acidic strata determined the depth to which root systems occurred $[3,38,39]$. The depth to which root systems occur controls the zone of influence of living organisms and organic compounds [40]. In QLS, roots ranged to $70 \mathrm{~cm}$ in depth and in TCS roots penetrated to $50 \mathrm{~cm}$. In those habitats, a marked flattening and deformation of pine root systems was observed. In natural conditions pines develop a typical taproot system. In the natural Haplic Podzol, the roots reached a depth of $90 \mathrm{~cm}$, and has been reported that roots of pine trees in natural conditions often reach a depth of several metres [41].

The spoil heap $\mathrm{pH}$ in quaternary strata was neutral or alkaline and $\mathrm{pH}_{\mathrm{KCl}}$ averaged 7.3 and $\mathrm{pH}_{\mathrm{H}_{2} \mathrm{O}}$ was 7.6. In organic $\mathrm{OL} / \mathrm{f}$ horizons, the $\mathrm{pH}$ was clearly acidic (4.1 $\mathrm{pH}_{\mathrm{KCl}}$ and $\mathrm{pH}_{\mathrm{H}_{2} \mathrm{O}}$ 4.4) which was due to the acidifying impact of organic litterfall under pine trees [41]. Soils on tertiary strata following neutralisation displayed different $\mathrm{pH}$ stratification in the soil profile. The highest $\mathrm{pH}$ occurred in the $0-8 \mathrm{~cm}$ layer of AiC horizon and averaged $5.7 \mathrm{pH}_{\mathrm{H}_{2} \mathrm{O}}$ and $4.9 \mathrm{pH}_{\mathrm{KCl}}$. Deeper, there was a decrease in $\mathrm{pH}$ to as low as $3.0 \mathrm{pH}_{\mathrm{H}_{2} \mathrm{O}}$ and $2.7 \mathrm{pH}_{\mathrm{KCl}}$. Sometimes higher content of bog lime resulted in $\mathrm{pH}_{\mathrm{H}_{2} \mathrm{O}}$ of up to 7.8 and $\mathrm{pH}_{\mathrm{KCl}}$ up to 7.4. It indicated considerable mi- 
cro-habitat variability in this type of plot. In natural soil, the lowest $\mathrm{pH}\left(4.3 \mathrm{pH}_{\mathrm{H}_{2} \mathrm{O}}\right.$ and $\left.3.5 \mathrm{pH}_{\mathrm{KCl}}\right)$ occurred in organic-mineral horizons with podzol features (AEes).

In the spoil heap, soil TEB (Total Exchangeable Bases) in QLS averaged from 26.5 to $27.6 \mathrm{cmol}(+) \cdot \mathrm{kg}^{-1}$, and CEC (Cation Exchange Capacity) from 27.0 to 28.0 $\mathrm{cmol}(+) \cdot \mathrm{kg}^{-1}$ (only in organic OL/f horizon did it increase to $\left.55.2 \mathrm{cmol}(+) \cdot \mathrm{kg}^{-1}\right)$. The highest TEB in mineral horizons (up to $35 \mathrm{cmol}(+) \cdot \mathrm{kg}^{-1}$ ) was related to higher ratios of sandy clays with up to $9 \%$ clay. In TCS, TEB was much lower and ranged from 2.3 to $4.7 \mathrm{cmol}(+) \cdot \mathrm{kg}^{-1}$, whereas CEC ranged from 5.0 to $5.8 \mathrm{cmol}(+) \cdot \mathrm{kg}^{-1}$. Also in this variant, organic $\mathrm{OL} / \mathrm{f}$ horizons exhibited the best exchange potential which is connected with excellent soil organic matter (SOM) exchange properties [42].

\subsection{Community Biomass}

Terrestrial ecosystems consist of above- and belowground components and their impact on one another is crucial for circulation of matter and energy flow [43,44]. Accumulation of elements in soil in the course of soil development processes, and especially the SOC sequestration potential in RMS, depends on the amount of biomass production and return to soil, and mechanisms of $\mathrm{C}$ protection [45].

The aboveground plant community biomass in QLS averaged $51.9 \mathrm{Mg} \cdot \mathrm{ha}^{-1}$, and in TCS it averaged $11.3 \mathrm{Mg} \cdot$ $\mathrm{ha}^{-1}$. These differences mainly resulted from the age and stage of development of the pine trees and not from habitat conditions. However, a 19-year-old pine tree on loamy quaternary sand in QLS had a $1.5 \times$ larger biomass than a 17-year-old pine tree in the control plot (Table 1).

Table 1. Biomass of individual components of the pine ecosystem on the top portion of 'Bełchatów' lignite mine spoil heap and in fresh mixed coniferous forest habitat.

\begin{tabular}{|c|c|c|c|c|c|c|}
\hline \multirow{2}{*}{$\begin{array}{l}\text { Variant } \\
\text { of site }\end{array}$} & \multicolumn{6}{|c|}{$\begin{array}{c}\text { Biomass } \\
\left(\text { dry biomass }\left(\mathrm{Mg} \cdot \mathrm{ha}^{-1}\right)\right)\end{array}$} \\
\hline & $\begin{array}{l}\text { Total } \\
\text { aboveground } \\
\text { biomass }\end{array}$ & Roots $^{1}$ & $\begin{array}{l}\text { Herbaceous } \\
\text { and shrubs }\end{array}$ & Trees & Wood $^{2}$ & Foliage \\
\hline QLS & $\begin{array}{c}51.876 \\
(12.436)\end{array}$ & $\begin{array}{c}6.570 \\
(1.057)\end{array}$ & $\begin{array}{c}0.134 \\
(0.085)\end{array}$ & $\begin{array}{c}51.741 \\
(12.454)\end{array}$ & $\begin{array}{c}43.535 \\
(10.693)\end{array}$ & $\begin{array}{c}8.206 \\
(1.770)\end{array}$ \\
\hline TCS & $\begin{array}{l}11.275 \\
(2.998)\end{array}$ & $\begin{array}{c}2.790 \\
(0.298)\end{array}$ & $\begin{array}{c}0.033 \\
(0.008)\end{array}$ & $\begin{array}{l}11.242 \\
(3.005)\end{array}$ & $\begin{array}{l}9.072 \\
(2.540)\end{array}$ & $\begin{array}{c}2.170 \\
(0.465)\end{array}$ \\
\hline $\begin{array}{l}\text { Control } \\
\text { NPE }\end{array}$ & 35.813 & 7.132 & 0.152 & 35.661 & 31.863 & 3.798 \\
\hline
\end{tabular}

Explanations: 394 (156) - mean (SD); ${ }^{1}$ in natural stand (NPE) community root biomass assumed to be 0.2 of wood biomass (according to $[46,47]) ;{ }^{2}$ - wood: large timber and branches of trees with $\mathrm{DBH}>7 \mathrm{~cm}$.
In the forest site and in the investigated spoil heap communities, stands of trees constituted the main component of aboveground biomass while the percentage of herbaceous vegetation did not exceed $0.3 \%-0.4 \%$. Compared to the total aboveground tree stands biomass, the root biomass amounted to $13 \%$ in QLS, and $25 \%$ in TCS, whereas the foliage biomass was $15 \%$ and $19 \%$ respecttively. Although the foliage comprised a small share of standing tree biomass, it made up a considerable part of annual icremental biomass production, frequently equal to that of woody tissue [48]. The typical aboveground tree biomass in forests of the temperate zone has been estimated at $21 \mathrm{Mg} \cdot \mathrm{ha}^{-1}$ (approx. 30-year-old stands of trees) and $170 \mathrm{Mg} \cdot \mathrm{ha}^{-1}$ (50-year-old stands of trees) [49]. In natural conditions on the Polish lowlands, the reported biomass of age group 1 (up to 20 year-old) stands of pine trees on average amounted to $50 \mathrm{Mg} \cdot \mathrm{ha}^{-1}$, but in the next age group it increased by nearly two-fold [50]. For four 17-year-old stands of pine trees on a reclaimed sand pit (in southern Poland) the biomass amounted to $25 \mathrm{Mg} \cdot \mathrm{ha}^{-1}$ [51]. So far, the tree biomass on the spoil heap has reached values which were close to natural conditions, and in the case of QLS, the biomass of 19-year-old stands of pine trees was higher than the control plot biomass. Very dynamic growth of the aboveground pine tree biomass on reclaimed soil was also reported in the Lusatian Mining District [8]. However, their data set refers to the first generation of stands of trees in age group 2 (i.e., not exceeding 40 years of age). It is currently difficult to predict whether the cycling of nutrient elements will be intensive enough and whether a self-sustainable ecosystem will develop with such growth of aboveground tree biomass in post-mining sites [28].

\subsection{Macronutrient Accumulation in Soil}

Low content of organic matter and related low total nitrogen and organic carbon accumulation are the common limiting features of reclaimed mine soils (RMS) [19]. Soil organic matter is especially important in determining other qualities of mine soils $[16,21,38,42,52]$. Total acc- umulation of organic carbon $\left(\mathrm{C}_{\mathrm{org}}\right)$ in both types of soils was similar and averaged over $54.0 \mathrm{Mg} \cdot \mathrm{ha}^{-1}$ (Table 2). The values were nearly $2 / 3$-fold lower than the natural soil in the control plot where $\mathrm{C}_{\text {org }}$ accumulation in the entire profile (up to $150 \mathrm{~cm}$ ) exceeded $75.5 \mathrm{Mg} \cdot \mathrm{ha}^{-1}$. In organic (O) and organic-mineral (AE) horizons of the podzol developed on fluvioglacial sands under forest, $\mathrm{C}_{\text {org }}$ accumulation ranged from 76.0 to $122.0 \mathrm{Mg} \cdot \mathrm{ha}^{-1}$. Carbon translocated to the enrichment horizon (B) should be added to this amount (the calculations have been made for Polish lowland habitat conditions on the basis of the Atlas of Polish forest soils; [53]). 
Table 2. Pool in the soil and accumulation of elements in the biomass in pine ecosystems on the top portion of 'Bełchatów' lignite mine spoil heap.

\begin{tabular}{|c|c|c|c|c|c|c|}
\hline \multirow{3}{*}{$\begin{array}{l}\text { Element } \\
\left(\mathrm{Kg}^{\left.-h^{-1}\right)}\right.\end{array}$} & \multicolumn{2}{|c|}{ In soil } & \multicolumn{4}{|c|}{ In biomass (aboveground dry biomass) } \\
\hline & $\begin{array}{c}\text { Organic } \\
\text { horizon }(\mathrm{LO} / \mathrm{f})\end{array}$ & $\begin{array}{l}\text { Organic-mineral and } \\
\text { mineral horizons } \\
\text { (AiC and C) } \\
\text { (up to } 110 \mathrm{~cm} \text { depth) }\end{array}$ & $\begin{array}{l}\text { Herbaceous and } \\
\text { shrubs }\end{array}$ & Wood $^{1}$ & Needles & Total $^{2}$ \\
\hline & \multicolumn{6}{|c|}{ Variant: QLS } \\
\hline $\mathrm{C}$ & $\begin{array}{l}1592.9 \\
(745.0)\end{array}$ & $\begin{array}{c}52709.2 \\
(42213.2)\end{array}$ & $\begin{array}{c}52.60 \\
(34.88)\end{array}$ & $\begin{array}{l}23700.7 \\
(4803.3)\end{array}$ & $\begin{array}{l}4492.0 \\
(710.2)\end{array}$ & $\begin{array}{l}28245.3 \\
(5497.3)\end{array}$ \\
\hline $\mathrm{N}$ & $\begin{array}{l}19.1 \\
(8.5)\end{array}$ & $\begin{array}{c}5021.2 \\
(1247.2)\end{array}$ & $\begin{array}{c}2.61 \\
(2.19)\end{array}$ & $\begin{array}{l}26.6 \\
(5.4)\end{array}$ & $\begin{array}{c}87.5 \\
(17.1)\end{array}$ & $\begin{array}{l}116.7 \\
(21.4)\end{array}$ \\
\hline $\mathrm{P}$ & $\begin{array}{c}1.8 \\
(1.0)\end{array}$ & $\begin{array}{c}27.4 \\
(17.6)\end{array}$ & $\begin{array}{c}0.24 \\
(0.16)\end{array}$ & $\begin{array}{c}6.2 \\
(1.3)\end{array}$ & $\begin{array}{c}9.5 \\
(1.6)\end{array}$ & $\begin{array}{l}15.9 \\
(2.8)\end{array}$ \\
\hline $\mathrm{K}$ & $\begin{array}{c}3.9 \\
(2.2)\end{array}$ & $\begin{array}{l}883.6^{*} \\
(269.6)\end{array}$ & $\begin{array}{c}3.76 \\
(1.83)\end{array}$ & $\begin{array}{l}29.8 \\
(6.0)\end{array}$ & $\begin{array}{c}49.6 \\
(11.1)\end{array}$ & $\begin{array}{c}83.2 \\
(16.7)\end{array}$ \\
\hline $\mathrm{Mg}$ & $\begin{array}{c}2.5 \\
(1.4)\end{array}$ & $\begin{array}{l}1288.9 * \\
(215.0)\end{array}$ & $\begin{array}{c}0.33 \\
(0.19)\end{array}$ & $\begin{array}{l}11.0 \\
(2.2)\end{array}$ & $\begin{array}{c}9.0 \\
(1.2)\end{array}$ & $\begin{array}{c}20.3 \\
(3.05)\end{array}$ \\
\hline $\mathrm{Na}$ & $\begin{array}{c}0.1 \\
(0.1)\end{array}$ & $\begin{array}{l}135.0 * \\
(24.0)\end{array}$ & $<0.00$ & $\begin{array}{c}0.82 \\
(0.17)\end{array}$ & $\begin{array}{c}0.25 \\
(0.28)\end{array}$ & $\begin{array}{c}1.1 \\
(0.42)\end{array}$ \\
\hline \multirow[t]{2}{*}{$\mathrm{S}$} & $\begin{array}{l}1.5 \\
(0.9) \\
\end{array}$ & $\begin{array}{c}4890.2 \\
(3069.5)\end{array}$ & $\begin{array}{c}0.74 \\
(0.72) \\
\end{array}$ & $\begin{array}{l}1.6 \\
(0.4) \\
\end{array}$ & $\begin{array}{l}35.3 \\
(7.7) \\
\end{array}$ & $\begin{array}{l}37.6 \\
(8.5) \\
\end{array}$ \\
\hline & \multicolumn{6}{|c|}{ Variant: TCS } \\
\hline $\mathrm{C}$ & $\begin{array}{l}1263.9 \\
(344.6)\end{array}$ & $\begin{array}{c}53479.6 \\
(27301.3)\end{array}$ & $\begin{array}{l}13.56 \\
(3.11)\end{array}$ & $\begin{array}{c}5925.3 \\
(2283.3)\end{array}$ & $\begin{array}{c}1411.2 \\
(438.3)\end{array}$ & $\begin{array}{c}7350.1 \\
(2717.7)\end{array}$ \\
\hline $\mathrm{N}$ & $\begin{array}{l}15.0 \\
(3.2)\end{array}$ & $\begin{array}{c}3042.5 \\
(1226.0)\end{array}$ & $\begin{array}{c}0.29 \\
(0.05)\end{array}$ & $\begin{array}{c}6.7 \\
(2.6)\end{array}$ & $\begin{array}{c}31.9 \\
(10.3)\end{array}$ & $\begin{array}{c}38.9 \\
(12.5)\end{array}$ \\
\hline $\mathrm{P}$ & $\begin{array}{c}1.8 \\
(0.1)\end{array}$ & $\begin{array}{l}27.6 \\
(4.7)\end{array}$ & $\begin{array}{c}0.02 \\
(0.00)\end{array}$ & $\begin{array}{c}1.6 \\
(0.6)\end{array}$ & $\begin{array}{c}3.2 \\
(1.1)\end{array}$ & $\begin{array}{c}4.8 \\
(1.7)\end{array}$ \\
\hline $\mathrm{K}$ & $\begin{array}{c}2.7 \\
(0.6)\end{array}$ & $\begin{array}{l}329.1^{*} \\
(45.6)\end{array}$ & $\begin{array}{c}0.44 \\
(0.06)\end{array}$ & $\begin{array}{c}7.4 \\
(2.9)\end{array}$ & $\begin{array}{l}20.1 \\
(6.8)\end{array}$ & $\begin{array}{l}27.9 \\
(9.6)\end{array}$ \\
\hline $\mathrm{Mg}$ & $\begin{array}{c}2.5 \\
(0.3)\end{array}$ & $\begin{array}{l}308.2 * \\
(140.9)\end{array}$ & $\begin{array}{c}0.03 \\
(0.01)\end{array}$ & $\begin{array}{c}2.8 \\
(1.1)\end{array}$ & $\begin{array}{c}2.4 \\
(0.8)\end{array}$ & $\begin{array}{c}5.2 \\
(1.9)\end{array}$ \\
\hline $\mathrm{Ca}$ & $\begin{array}{l}29.6 \\
(7.4)\end{array}$ & $\begin{array}{l}9778.1 * \\
(3215.4)\end{array}$ & $\begin{array}{c}0.16 \\
(0.08)\end{array}$ & $\begin{array}{l}10.5 \\
(4.1)\end{array}$ & $\begin{array}{c}9.4 \\
(3.5)\end{array}$ & $\begin{array}{l}20.1 \\
(7.5)\end{array}$ \\
\hline $\mathrm{S}$ & $\begin{array}{c}1.3 \\
(0.2)\end{array}$ & $\begin{array}{c}4914.0 \\
(2376.6)\end{array}$ & $\begin{array}{c}0.02 \\
(0.01)\end{array}$ & $\begin{array}{c}0.3 \\
(0.1)\end{array}$ & $\begin{array}{l}10.8 \\
(5.0)\end{array}$ & $\begin{array}{l}11.1 \\
(5.1)\end{array}$ \\
\hline
\end{tabular}

Explanations: 19.1 (8.5) - mean (SD); $\mathrm{n}=4$ (number of plots in variant); ${ }^{1}$ wood biomass of trees with DBH $>7 \mathrm{~cm} ;{ }^{2}$ total element's accumulation in aboveground biomass (trees, herbaceous and shrubs biomass), *differences for soil element's resource are significant at $p=0.05$ level (T-student test).

Nitrogen (and phosphorus) is one of the most deficient elements in reclaimed sites [5,54]. In the spoil heap soils of former lignite mines developing on tertiary carboniferous sands, geological carbon in the form of lignites often occurs and complicates soil $\mathrm{C}$ analysis. Therefore, the $\mathrm{C}$ and $\mathrm{N}$ accumulation rate in the deeper horizons of the spoil heap soils, especially in case of TCS, may actually be overestimated. Although total $\mathrm{N}$ accumulation increases in the course of soil development in mine soils, both in those undergoing reclamation treatment and those where natural succession is taking place $[5,12$, $14,38]$, it has been found that the average annual accumulation of $\mathrm{N}$ fluctuates and may change with the age of soil and vary by community type introduced in reclamation seedings [38].

Moreover, $\mathrm{N}$ accumulation is much less dynamic than carbon accumulation [14]. Also, in soils where primary succession takes place, $\mathrm{N}$ is gradually mineralised [54] which may be deficient for rapidly growing young trees in reclaimed areas which require a lot of $\mathrm{N}$ over time [8]. Total accumulation of $\mathrm{N}_{\mathrm{t}}$ in QLS soils was on average $5.0 \mathrm{Mg} \cdot \mathrm{ha}^{-1}$, and therefore $2 / 3$-fold higher than in TCS soils where it amounted to $3.0 \mathrm{Mg} \cdot \mathrm{ha}^{-1}$. In comparable natural soils, $\mathrm{N}$ accumulation was much higher at 11.0 $\mathrm{Mg} \cdot \mathrm{ha}^{-1}$.

The highest accumulation of exchangeable $\mathrm{Ca}^{2+}, \mathrm{Mg}^{2+}$, $\mathrm{K}^{+}, \mathrm{Na}^{+}$, and available $\mathrm{P}$ in mineral horizons took place in QLS on Quaternary strata, and in all cases (except for sulphur) it was considerably higher $(p=0.05)$ than in TCS (Table 2). High sulphur accumulation $\left(\mathrm{S}_{\mathrm{t}}\right)$, reaching $4.9 \mathrm{Mg} \cdot \mathrm{ha}^{-1}$, was related to the properties and origin of spoil heap strata. Soils developing on Tertiary carboniferous and pyritic strata may contain more than $1 \%$ sulphur and are referred to as "sulphurous mine soils" 
[33]. The nutrient resources accumulated in mineral horizons of a comparable natural podzol were much lower than in QLS with $\mathrm{Ca}^{2+}=132 ; \mathrm{Mg}^{2+}=42 ; \mathrm{K}^{+}=16 ; \mathrm{P}=$ 1.4 ; and $\mathrm{Na}^{+}=2.5$-fold lower, respectively, than in TCS with $13 ; 10 ; 6 ; 1.3$; and 1.7-fold respectively. According to a habitat classification based on the Soil Quality Index used in forestry in Poland [53], QLS soils could be even classified higher than natural deciduous forest sites (eutrophic). The accumulation ratio of individual elements in mineral horizons (up to $110 \mathrm{~cm}$ depth) and in organic horizons - raw humus layer OL/f in RMS and $\mathrm{Ol}+\mathrm{Olf}$ in Haplic Podzol $\left(\mathrm{MH}_{\mathrm{BA}}: \mathrm{OH}_{\mathrm{BA}}\right)$ (Table 3) constituted a major difference in the distribution of elements accumulated in RMS on the spoil heap and in the comparable Haplic Podzol. In initial mine soils, the OL/f horizons were still insufficiently developed and did not have a sufficient pool of macronutrients.

Furthermore, SOM accumulation, decomposition, and mineralization were probably not well established enough to meet the nutrient supply needs for vegetation as in natural forest habitats $[29,55]$. In the oligotrophic Haplic Podzol, the resources of elements in mineral horizons were the same (in case of $\mathrm{C}$ and $\mathrm{Na}$ ), and nearly the same $(\mathrm{Ca}, \mathrm{Mg}$ and $\mathrm{K}$ ) or even lower $(\mathrm{P})$, and only in exceptional cases such as nitrogen $\left(\mathrm{MH}_{\mathrm{BA}}: \mathrm{OH}_{\mathrm{BA}}\right.$ accumulation was 4.6) and sulphur $\left(\mathrm{MH}_{\mathrm{BA}}: \mathrm{OH}_{\mathrm{BA}}\right.$ was 558) was it many times higher in comparison to resources in the organic horizons (Table 3 ).

Table 3. The ratio of the accumulation of macronutrient resources in soil mineral horizons to accumulation in organic soil horizon $\left(\mathrm{MH}_{\mathrm{BA}}: \mathrm{OH}_{\mathrm{BA}}\right)$ and of biomass to soils $\left(\mathrm{B}_{\mathrm{BA}}: \mathrm{S}_{\mathrm{BA}}\right)$ on the spoil heap of KWB 'Bełchatów' in Quaternary loamy sand strata (QLS variant) and in Tertiary carboniferous and pyritic sands following neutralisation (TCS variant) and in a natural pine ecosystem on Haplic Podzol in fresh mixed coniferous forest habitat (NPE).

\begin{tabular}{ccccccccc}
\hline $\begin{array}{c}\text { Variant of } \\
\text { site/ } \\
\text { element }\end{array}$ & $\mathrm{C}$ & $\mathrm{Ca}$ & $\mathrm{Mg}$ & $\mathrm{K}$ & $\mathrm{P}$ & $\mathrm{S}$ & $\mathrm{Na}$ & $\mathrm{N}$ \\
\hline QLS & 33.09 & 3471.73 & 515.56 & 226.60 & 15.54 & 3343.72 & 964.04 & 263.03 \\
$\mathrm{TCS}$ & 42.34 & 330.26 & 192.30 & 120.88 & 19.33 & 3780.00 & 826.40 & 203.14 \\
$\mathrm{NPE}$ & 0.99 & 1.24 & 0.64 & 0.62 & 0.34 & 558.20 & 0.96 & 4.64 \\
\hline & & \multicolumn{7}{c}{$\mathrm{MH}_{\mathrm{BA}}: \mathrm{OH}_{\mathrm{BA}}$} \\
\hline QLS & 0.54 & 0.001 & 0.02 & 0.09 & 0.58 & 0.008 & 0.008 & 0.023 \\
$\mathrm{TCS}$ & 0.14 & 0.002 & 0.02 & 0.08 & 0.19 & 0.002 & 0.003 & 0.013 \\
$\mathrm{NPE}$ & 0.63 & 0.45 & 15.42 & 4.70 & 4.05 & 0.023 & 0.072 & 0.266
\end{tabular}

Explanation: values calculated based on mean for variants; $\mathrm{MH}$ - soil mineral horizons up to $110 \mathrm{~cm}$ depth; $\mathrm{BA}$ - element accumulation or source in $\left(\mathrm{Mg} \cdot \mathrm{ha}^{-1}\right) ; \mathrm{OH}$ - organic horizons (row humus layer OL/f in reclaimed soil and $\mathrm{Ol}+$ Olf in Haplic Podzol); B - aboveground biomass; S - soil; variant's abbreviation and element's form in soil - see methodology chapter

\subsection{Relationships between Elements in Soil}

The ( $\mathrm{C}: \mathrm{N}$ ratio) may be regarded as an indicator of changes in soils including intensification of organic matter mineralisation processes and related $\mathrm{N}$-availability to plants during the decomposition of organic matter in soil [29]. In the investigated spoil heap, the soil C:N ratio in the $\mathrm{OL} / \mathrm{f}$ horizon exceeded 80, whereas in QLS variant in the AiC horizon was 11 and in TCS variant it was 16 . In the control podzol the $\mathrm{C}: \mathrm{N}$ ratio in organic horizons was lower and was 51, and in the organic-mineral horizon (AEes) it was 17. For mor type humus characteristic of podzols in temperate climatic zones, the $\mathrm{C}: \mathrm{N}$ ratio in organic and organic-mineral horizons oscillates between 30 and 40 and sometimes reached higher values [29]. Scots pine as a species characteristic of coniferous forests produces organic litterfall which decomposes with difficulty and the C:N ratio usually exceeded 70 [41]. It was assumed that for initial soils on post-mining sites, the C:N ratio in organic-mineral horizons below 25 would indicate regular mineralization processing of organic matter [56].

The potential of the developing mine soils to meet plant nutrient requirements depended on the percentage of elements in forms available for plants (for this study: $\mathrm{Na}^{+}, \mathrm{K}^{+}, \mathrm{Ca}^{2+}, \mathrm{Mg}^{2+}$ in exchangeable form and available $\mathrm{P})$. In the organic horizons, these forms depended directly on the decomposition rate and mineralization of organic matter developed in situ. In mineral horizons, they largely depended on the weathering rate of minerals in the substrate. In natural habitats and especially in oligotrophic podzols, nutrients were mainly stored in the organic horizons and they were gradually released via mineralization processes [29]. This was of key importance in providing nutrients to trees as a limited amount of nutrients in soil could be compensated for by quick biological cycling of elements [55]. Soil organic matter (SOM), even though in its initial phase of accumulation, plays an important role in the tree nutrition balance in reclaimed areas $[42,52,57]$. In the investigated podzol, the highest percentage of exchangeable $\mathrm{Ca}^{2+}, \mathrm{Mg}^{2+}, \mathrm{Na}^{+}$ and $\mathrm{P}$ (in available form) compared to total forms occurred in organic horizons ( $\mathrm{Ol}$ and $\mathrm{Ofh} ; 0-9 \mathrm{~cm})$ and amounted to $43,49,35$ and $18 \%$, respectively of the total elemental pool. In the case of $\mathrm{K}^{+}$, the highest percentage of exchangeable forms in the total pool of elements occurred in the enrichment horizon (Bfe, 50-94 cm) and amounted to 6\% (Figure 1). In RMS (QLS), the most favourable relationship in this respect also occurred in organic horizons OL/f $(0-2 \mathrm{~cm})$, where $\mathrm{Mg}^{2+}$ amounted to $41 \%$ (of total $\mathrm{Mg}$ ) whereas $\mathrm{Ca}^{2+}$ was $24 \%$; $\mathrm{K}^{+}=$ $43 \% ; \mathrm{Na}^{+}=24 \%$ and $\mathrm{P}$ was $=19 \%$ of the total elemental pool (Figure 1). 


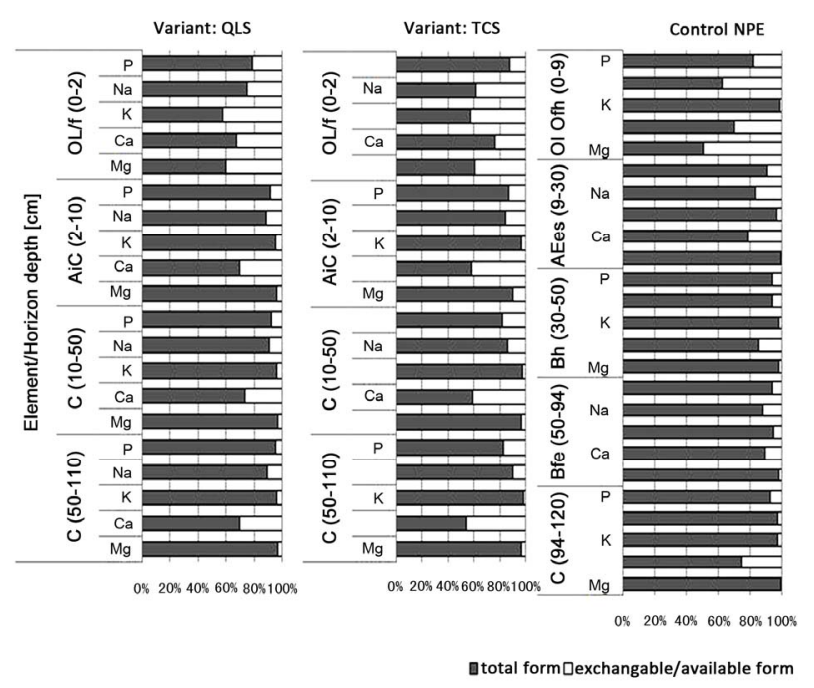

Figure 1. The share of exchangeable and available forms of the total macronutrient elemental pool in spoil heap soils of KWB 'Bełchatów' in Quaternary loamy sand strata (QLS variant) and in Tertiary carboniferous and pyritic sands following neutralisation (TCS variant) and in a natural pine ecosystem on Haplic Podzol in fresh mixed coniferous forest habitat (NPE).

In mineral horizons, the percentage of exchangeable and available forms decreased. However, in comparison to natural soils, the percentage of exchangeable forms in the entire pool of macronutrient elements was considerably higher. In the deeper mineral horizons, nutrients were mainly supplied due to weathering of minerals. In the more shallow horizons, what was also important was the enrichment process occurring via soil development where organic matter, colloidal fractions and sesquioxides were being supplied from the organic layers [58]. In QLS soils in the OL/f horizon $(0-2 \mathrm{~cm})$, similar relationships were noted for $\mathrm{Mg}^{2+}, \mathrm{K}^{+}$, and $\mathrm{Na}^{+}$. Exchangeable forms of these elements constituted approximately $40 \%$ of the total elemental pool in total form. However in the case of $\mathrm{Ca}^{2+}$ and $\mathrm{P}$, the largest percentage of forms available to plants occurred in mineral layers: $\mathrm{P}$ at $17 \%$ from 10 to $50 \mathrm{~cm}$, and $\mathrm{Ca}^{2+}$ at $46 \%$ from 50 to 110 (Figure 1). This was clearly connected with the bog lime neutralization treatment which was incorporated to a depth of at least $30 \mathrm{~cm}$.

\subsection{Relationships between Element AccuMulation in Soils and Aboveground Biomass}

Relations between soils and vegetation under natural conditions have long been studied and soil development and ecological succession of communities are closely linked $[26,47,59]$. In reclaimed post-mining sites these relationships are not yet stable and may be frequently disturbed. Clear links between the trophism of mine soils (as expressed by Soil Trophy Index (according to Brożek and Zwydak [53]), and ecological indicators based on Ecological Indicator Values of Vascular Plants (according to Ellenberg, [60]) have been documented in sand pits where natural succession was allowed to occur ('Szczakowa' sand mine pit in southern w Poland; Pietrzykowski and Krzaklewski [61]). Relationships between community features and abundance of soils developing on former mining sites under succession were also described by Wali [14] on the bases of studies of abandoned coal-mine spoil materials in a mixed grass prairie region (in western North Dakota, USA).

For this spoil heap, the ratio of elements accumulated in the aboveground biomass to the resources in soil mineral horizons $\left(\mathrm{B}_{\mathrm{BA}}: \mathrm{S}_{\mathrm{BA}}\right)$ differed largely from the control plot in the mixed coniferous forest, especially for $\mathrm{Ca}$, $\mathrm{Mg}, \mathrm{K}$ and $\mathrm{P}$. Communities in reclaimed areas accumulated considerably less of those elements in relation to the potential resources (Table 3). For biomass in the forest habitat, the $\mathrm{B}_{\mathrm{BA}}: \mathrm{S}_{\mathrm{BA}}$ ratio was much higher, which indicates that the elements available in soil were much better utilized by those communities. On this basis, it may also be claimed that the element exchange mechanism by pine communities on the spoil heap has different dynamics than in natural habitats. A dependence analysis between the accumulation of nutrients (in exchangeable and available forms expressed in $\mathrm{Mg} \cdot \mathrm{ha}^{-1}$ to a depth of $110 \mathrm{~cm}$ ) and elements accumulated in community biomass showed a significant linear correlation ( $p=0.05$ ) for $\mathrm{K}, \mathrm{Ca}$ and $\mathrm{Mg}$ (Table 4). This indicates the existence of marked relationships between the abundance of soil nutrients available to plants and the level of elements accumulated in community biomass developing on the spoil heap. Under natural conditions, such obvious dependence occurs in the first stages of primary succession where plant communities depend directly upon elements from the parent rock transformed into soil $[26,49]$. In the more complex conditions of natural forest ecosystems there are many other variables which modify these factors, including organic matter decomposition rate, individual biochemical cycles of elements, and the soil volume used by tree root systems which was difficult to determine in this study.

\section{CONCLUSIONS}

The highest aboveground pine stand biomass occurred in QLS on quaternary strata, However when compared to TCS on less abundant tertiary sands following neutrallization, lower biomass resulted from age differences (19 and 12 years), and not just from differences in habitat 
Table 4. A table of correlations between resources of macronutrient elements $\left(\mathrm{Mg} \cdot \mathrm{ha}^{-1}\right)$ in mineral soil horizons to $110 \mathrm{~cm}$ depth versus those in aboveground pine tree stand biomass on the upper portion of "Bełchatów" lignite mine spoil heap.

\begin{tabular}{|c|c|c|c|c|c|c|c|c|c|}
\hline \multicolumn{10}{|c|}{ In biomass (aboveground biomass: trees and herbaceous vegetation) } \\
\hline$\overline{0}$ & $\left(\mathrm{Mg} \cdot \mathrm{ha}^{-1}\right)$ & C-biom & N-biom & S-biom & P-biom & K-biom & Ca-biom & Mg-biom & Na-biom \\
\hline$\cong$ & C-soil & 0.18 & 0.11 & 0.30 & 0.17 & 0.31 & 0.22 & 0.11 & 0.09 \\
\hline 犬ี ح & $\mathrm{N}_{\mathrm{t}}$-soil & 0.55 & 0.59 & 0.55 & 0.57 & 0.52 & 0.58 & 0.61 & 0.44 \\
\hline 言 & $\mathrm{S}_{\mathrm{t}}$-soil & 0.03 & -0.01 & -0.10 & 0.05 & 0.02 & 0.01 & 0.02 & -0.06 \\
\hline $\bar{\pi}$ & P-soil & -0.05 & 0.04 & -0.17 & -0.03 & -0.18 & -0.07 & 0.03 & 0.06 \\
\hline. $\bar{\Xi}$ & $\mathrm{K}^{+}$-soil & $0.80 *$ & 0.74 & 0.84 & 0.78 & 0.85 & 0.82 & 0.78 & 0.61 \\
\hline है & $\mathrm{Ca}^{2+}$-soil & 0.92 & 0.90 & 0.91 & 0.92 & 0.92 & 0.93 & 0.93 & 0.79 \\
\hline$\overline{0}$ & $\mathrm{Mg}^{2+}$-soil & 0.82 & 0.80 & 0.81 & 0.82 & 0.82 & 0.83 & 0.85 & 0.67 \\
\hline$\Xi$ & $\mathrm{Na}^{+}$-soil & 0.62 & 0.56 & 0.59 & 0.61 & 0.64 & 0.62 & 0.62 & 0.37 \\
\hline
\end{tabular}

*marked differences are significant at $p=0.05 ; \mathrm{n}=8 ; \mathrm{N}_{\mathrm{t}}$ - total nitrogen; $\mathrm{S}_{\mathrm{t}}$ - total sulphar; $\mathrm{K}^{+}$- exchangeable cation forms - see methodology chapter.

conditions between the plots. The higher community biomass in QLS (2/3-fold) on the spoil heap compared to pine tree stand biomass in the control plot in natural habitat indicated that quaternary loamy sand strata was potentially a good soil substrate for this species. Total accumulation of organic carbon $\left(\mathrm{C}_{\text {org }}\right)$ in both soil variants was 2/3-fold lower, and in case of total $\mathrm{N}_{\mathrm{t}}$, more than 3 -fold lower when compared to natural soil in the control plot. Nitrogen was the most deficient element in those conditions. The accumulation and the biogeochemical cycling of carbon and nitrogen were closely linked with the processes of soil development and community development on the spoil heap. The accumulation of these elements was a good indicator of the rate of these processes. In case of the exchangeable cations $\left(\mathrm{Ca}^{2+}, \mathrm{Mg}^{2+}, \mathrm{K}^{+}, \mathrm{Na}^{+}\right)$in the mineral RMS horizons, their accumulation was mostly connected with the potential abundance of rock strata and weathering processes during the development of soil. This was why the resources of these elements were considerably higher in the spoil heap soil than in the Haplic Podzol which formed on oligotrophic fluvioglacial sands. The higher (statistically significant) resources of macronutrients in QLS soils on quaternary strata compared to TCS soils on tertiary sands were also related to the origin and properties of parent rocks of the developing soil. Since this feature clearly differentiated the degrees of soil nutrient abundance on the spoil heap, it may be used to develop a habitat condition indicator for these materials.

A significant difference between RMS soils and natural Haplic Podzols were the accumulation ratios of individual elements in mineral and organic horizons $\left(\mathrm{MH}_{\mathrm{BA}}\right.$ : $\left.\mathrm{OH}_{\mathrm{BA}}\right)$. In the case of mine soils, the initial organic horizons did not yet constitute a significant source of nutrients and SOM accumulation and decomposition were not the basic mechanism for supplying plants with nutrients as is the case in natural forest habitats. There were also differences in the ratio of elements accumulated in aboveground biomass to the potential sources in soil $\left(\mathrm{B}_{\mathrm{BA}}: \mathrm{S}_{\mathrm{BA}}\right)$ on the spoil heap and in the control plot, particularly for $\mathrm{Ca}, \mathrm{Mg}, \mathrm{K}$ and $\mathrm{P}$. Plant communities in reclaimed area accumulated much fewer elements compared to potential sources in soil. However, for plant biomass in forest habitats of the oligotrophic Haplic Podzol, the ratio was much higher and indicated that macronutrient resources in soil were optimally utilized by the plant community. On this basis it may be assumed that the exchange mechanism of elements by plant communities dominated with pine on the spoil heap had different dynamics than in natural habitats. Moreover, the reported correlations between the accumulation of nutrients in soil and elements accumulated in plant community biomass (most clearly in the case of $\mathrm{K}, \mathrm{Ca}$ and $\mathrm{Mg}$ ), indicates the existence of marked links between soil and vegetation in the process of ecosystem development on a former mining spoil heap as stimulated by reclamation treatments.

\section{ACKNOWLEDGEMENTS}

This study was financially supported by a grant from Norway through the Norwegian Financial Mechanism. The author also thanks Professor W. Lee Daniels Ph.D. from Virginia Tech for critical text correction; Jarosław Socha Ph.D. from Department of Forest Mensuration for his kind assistance in the process of preparing statistical analysis, and laboratory staff of Department of Forest Ecology and Department of Forest Soil Science ACU Krakow, Poland.

\section{REFERENCES}

[1] Bradshow, A.D. and Chadwick, M.J. (1980) The restoration of Land. The Ecology and reclamation of derelict and degraded land. Blackwell Scientific Publications, Oxford.

[2] Bradshaw, A.D. and Hüttl, R.F. (2001) Future minesite restoration involves a broader approach. Ecolgical Engi- 
neering, 17(2-3), 87-90

[3] Daniels, W.L., Genthner, M.H. and Hodges, R.L. (1992) Soil development in sandy tailings derived form mineral sands mining in Florida. Proceedings of the 9th National Meeting of the American Society for Surface Mining and Reclamation, Duluth, 14-18 June 1992, ASSMR, Lexington, 37-47.

[4] Daniels, W.L., Alley, M.M., Zelazny, L.W. and Schroeder, P. (1996) Strategies for rehabilitating prime farmland following mineral sands mining in Virginia. Annual Research Report, Submitted to RGC (USA) Mineral Sands Inc, 1-20.

[5] Daniels, W.L., Schroeder, P.D., Nagle, S.M., Zelazny, L.W. and Alley, M.M. (1999) Reclamation of prime farmland following mineral sands mining in Virginia. Proceedings of the 16th National Meeting of the American Society for Surface Mining and Reclamation, "Mining and reclamation for the Next Millennium", Scottsdale, Arizona, 13-19 August 1999, ASSMR, Lexington, 146156.

[6] Daniels, W.L., Evanylo, G.K., Nagle, S.M. and Schmidt, J.M. (2001) Effects of biosolids loading rate and sawdust additions on row crop yield and nitrate leaching potentials in Virginia sand and gravel mine reclamation and Reclamation-A different approach. Proceedings of the 18th National Meeting of the American Society for Surface Mining and Reclamation, Albuquerque, 3-7 June 2001, ASSMR, Lexington, 2, 399-406.

[7] Daniels, W.L., Nagle, S., Whittecar, G.R. and Evenylo, G. (2002) Effect of Biosolides application on ground water nitrate-N levels in sand and gravel mine reclamation in Virginia. Proceedings of the 19th National Meeting of the American Society for Surface Mining and Reclamation, Lexington, 9-13 June 2002, ASMR, 99-113.

[8] Hüttl, R.F. and Weber, E. (2001) Forest ecosystem development in post-mining landscapes, a case study of the Lusatian lignite district. Naturwissenschaften, 88(8), 322-329

[9] Krzaklewski, W. (1982) Die Möglichkeiten der ausnutzung der natürlichen vegetation in der rekultivierung der Nachabbaugelände (Abraum-oder Bergehalden). Kommunalverband Ruhrgebit Conference, Essen, 7-10 September 1982.

[10] Pietrzykowski, M. (2006) Properties of soils formed on reclaimed areas and areas left for succession on post-exploitation sand filing excavation (in Polish, English summary). Soil Science Annual, 57(3-4), 97-105.

[11] Pietrzykowski, M. and Krzaklewski, W. (2007a) An assessment of energy efficiency in reclamation to forest. Ecological Engineering, 30(4), 341-348

[12] Pietrzykowski, M. and Krzaklewski, W. (2007b) Soil organic matter, $\mathrm{C}$ and $\mathrm{N}$ accumulation during natural succession and reclamation in an opencast sand quarry (southern Poland). Archives of Agronomy and Soil Science, 53(5), 473-483

[13] Urbanska, K.M., Webb, N.R. and Edwards, P.J. (Eds.) (1997) Restoration Ecology and Sustainable development. Cambridge University Press, New York.

[14] Wali, M.K. (1999) Ecological succession and the rehabilitation of disturbed terrestrial ecosystems. Plant and Soil, 213(1-2), 195-220.

[15] Wali, M.K. and Freeman, P.G. (1973) Ecology of some mined areas in North Dakota. in: Wali, M.K., Eds., Some Environmental Aspects of Strip Mining in North Dakota. Education Series 5, North Dakota Geological Survey, Grand Froks, 25-47.

[16] West, T.O. and Wali, M.K. (2002) Modeling regional carbon dynamics and soil erosion in disturbed and rehabilitated ecosystems as affected by land use and climate. Water, Air and Soil Pollution, 138(1-4), 41-163.

[17] Golley, F.B. (1993) History of the Ecosystem Concept in Ecology. Yale University Press, New Haven.

[18] Rodrigue, J.A., Burger, J.A. and Oderwald, R.G. (2002) Forest productivity and commercial value of pre-law reclaimed mined land in the eastern United States. Northern Journal of Applied Forestry, 19(3), 106-114

[19] Bendtfeldt, E.S., Burger, J.A. and Daniels, W.L. (2001) Quality of amended mine soils after sixteen years. Soil Science Society of America Journal, 65, 1736-1744

[20] Bradshaw, A.D. (1983) The reconstruction of ecosystems. Journal of Applied Ecology, 20, 1-17

[21] Li, R.S. and W.L. Daniels (1994) Nitrogen accumulation and form over time in young mine soils. Journal of Environmental Quality, 23, 166-172

[22] Schaaf, W. (2001) What can element budgets of false-time series tell us about ecosystem development on post-lignite mining sites? Ecological Engineering, 17(23), 241-252

[23] Jochimsen, M.E.A. (1996) Reclamation of colliery mine spoil founded on natural succession. Water Air Soil Pollution, 91(1-2), 99-108

[24] Pietch, W.H.O. (1996) Recolonization and development of vegetation on mine spoils following brown coal mining in Lusatia. Water Air Soil Pollution, 91(1-2), 1-15.

[25] Wiegleb, G. and Felinks, B. (2001) Primary succession in post-mining landscapes of lower Lusatia-Chance or necessity. Ecological Engineering, 17(2-3), 199-217.

[26] Odum, E. (1971) Fundamentals of ecology. 3rd Edition, W. B. Saunders Co., Philadelphia.

[27] Bell, L.C. (2001) Establishment of native ecosystems after mining-Australian experiences across diverse biogeographic zones. Ecological Engineering, 17(2-3), 179189

[28] Knoche, D., Embacher A. and Katzur, J. (2002) Water and element fluxes of red oak ecosystems during stand development on post-mining sites (Lusatian Lignite District). Water, Air, and Soil Pollution, 141(1-4), 219-231

[29] Baule, H. and Fricker, C. (1970) The fertilizer treatment of forest trees. BLV-Verlagsges, Munchen.

[30] Baumann, K., Rumpelt, A., Schneider, B.U., Marschner, P. and Hüttl, R.F. (2006) Seedling biomass and element content of Pinus sylvestris and Pinus nigra grown in sandy substrates with lignite. Geoderma, 136, 573-578

[31] Fober, H. (1993) Żywienie mineralne. In: Białobok, S., Boratyński, A. and Bugała, W., Eds., Biologia sosny zwyczajnej, PAN Instytut Dendrologii, Sorous Press, Poznań-Kórnik, 182-193

[32] Woś, A. (1999) Climate of Poland (Klimat Polski) (in Polish). PWN Press, Warsaw.

[33] Katzur, J. and Haubold-Rosar, M. (1996) Amelioration and reforestation of sulfurous mine soils in Lusatia (Eastern Germany). Water, Air and Soil Pollution, 91(1-2), 17-32

[34] Krzaklewski, W., Kowalik, S. and Wójcik, J. (1997) Re- 
clamation of acidic and toxic strata in brown coal opencast mining. MONOS Press, Krakow.

[35] Ostrowska, S., Gawlinski, Z. and Szczubialka, Z. (1991) Procedures for soil and plants analysis (in Polish). Institute of Environmental Protection, Warsaw.

[36] Van Reeuwijk, L.P. (1995) Procedures for soil analysis. 5th Edition, Technical Paper 9, ISRIC, FAO, Wageningen.

[37] FAO-UNESCO (1997) Soil map of the World-revised legend. ISRIC, Wageningen.

[38] Anderson, D.W. (1977) Early stages of soil formation of glacial till mine spoils in semiarid climate. Geoderma, 19(1), 11-19.

[39] Fabijanowski, J. and Zarzycki, K. (1969) Spontane Vegetation als Grundlage für die Haldenaufforstung in Piaseczno bei Tarnobrzeg (Südospolen). Beiheft $z u$ den Zeitschriften des Schweizerischen Forstvereins, 46, 271280.

[40] Bednarek, R. and Prusinkiewicz, Z. (1997) Soil geography (Geografia Gleb). PWN, Warsaw.

[41] Obmiński, Z. (1970) Zarys ekologii. in: Białobok, S., Ed., Nasze Drzewa Leśne, Monografie Popularnonaukowe, Sosna Zwyczajna (Pinus silvestris L.), Wydawnictwo Naukowe PWN.) Warszawa-Poznań, 203-231.

[42] Ellerbrock, R.H., Höhn, A. and Gereke, H.H. (1999) Characterization of soil organic matter from a sandy soil in relation to management practice using FT-IR spectroscopy. Plant and Soil, 213(1-2), 55-61

[43] Odum, H.T. and Odum, B. (2003) Concepts and methods of ecological engineering. Ecological Engineering, 20(5), 339-361

[44] Wardle, D.A., Bardgett, R.D., Klironomos, J.N., Setälä, H., Van der Putten, W.H., Wall D.H. (2004) Ecological Linkages between aboveground and underground biota. Science, 304(5677), 1629-1633

[45] Shrestha, R.K. and Rattan L. (2006) Ecosystem carbon budgeting and soil carbon sequestration in reclaimed mine soil. Environment International, 32(6), 781-796

[46] Lieth, H. and Whittaker, R.F. (1975) Primary productivity of the biosphere. Springer Verlag, Berlin-Heidelberg-New York.

[47] Miller, A.T., Allen, H.L. and Maier, C.A. (2006) Quantifying the coarse-root biomass of intensively managed loblolly pine plantations. Canadian Journal of Forest Research, 36, 12-22.

[48] Assmann, E. (1970) The principles of forest yield study: Studies in the organic production, structure, increment, and yield of forest stands. Pergamon Press, Oxford.
[49] Krebs, C.J. (2001) Ecology. The Experimental Analysis of Distribution and Abundance. Wydawnictwo Naukowe PWN, Warsaw.

[50] Orzeł, S., Socha, J., Forgiel, M. and Ochał, W. (2005) Biomass and annual production of mixed stands of the Niepołomice Forest (in Polish, English summary). Act. Sci. Pol., Silv. Colendar. Rat. Ind. Lignar, 4(2), 63-79.

[51] Pietrzykowski, M. (2005) Characteristics of selected features of arborescent vegetation in reclaimed areas and in areas left for succession as exemplified by experimental plots in the Szczakowa sand mine excavation (in Polish, English summary). Acta Agr. Silv. Ser. Silv., 63, 1-26.

[52] Roberts, J.A., Daniels, W.L., Bell, J.C. and Burger, J.A. (1988) Early stages of mine soil genesis in a southwest Virginia spoil lithosequence. Soil Science Society of America Journal, 52, 716-723

[53] Brożek, S. and Zwydak, M. (2003) Atlas of forest soils in Poland (in Polish). Atlas Gleb Leśnych Polski, CILP Press, Warsaw.

[54] Marrs, R. and Bradshaw A.D. (1993) Primary succession on man-made wastes: The importance of resource acquisition. In: Miles, J. and Walton, D.W.H., Eds., Primary Succession of Land, Blackwell Scientific Publications, Oxford, 221-247.

[55] Puchalski, T. and Prusinkiewicz, Z. (1975) Ecological background for forest site classification (in Polish). PWRiL Press, Warsaw.

[56] Harmsen, G.W. and Kolenbrander, G.J. (1965) Soil inorganic nitrogen. In: Bartholomew, W.V. and Clark, F.E., Eds., Soil Nitrogen, American Society of Agronomy, Madison, 43-92.

[57] Rumpel, C., Kögel-Knabner, I. and Hüttl, R.F. (1999) Organic matter composition and degree of humification on lignite-rich mine soils under a chronosequence of pine. Plant and Soil, 213(1-2), 161-168.

[58] Dobrzański, B. and Zawadzki, S. (1995) Pedology (Gelboznawstwo) (in Polish). PWRiL Press, Warsaw.

[59] Braun-Blanquet J. (1964) Pflanzensoziologie, Grundlage der Vegetationskunde (3 Aufl). Springer, New York.

[60] Ellenberg, H. (1979) Zeigerwerte der Gefäßpflanzen Mitteleuropas. Scripta Geobotanica, 9, 7-122.

[61] Pietrzykowski, M. and Krzaklewski, W. (2006) Functionality assessment of soil quality index (ITGL) and vascular plant ecological indicator for site quality diagnosis in a sand mine excavation. Acta Sci. Pol. Silv. Colendar. Rat. Ind. Lignar, 5(1), 47-56 